\title{
The Anarchical Society as Futurology
}

\section{Patomäki, Heikki Olavi}

Oxford University Press

2017-06-15

Patomäki , H O 2017 , The Anarchical Society as Futurology . in M Carr , A Humphreys \& H Suganami (eds), The Anarchical Society at 40 : Contemporary Challenges and Prospects . Oxford University Press, Oxford , pp. 253-269 . < https://global.oup.com/academic/product/the-anarchical-society-at-40-9780198805144?cc=fi\&lang=en\& $>$

http://hdl.handle.net/10138/303138

acceptedVersion

Downloaded from Helda, University of Helsinki institutional repository.

This is an electronic reprint of the original article.

This reprint may differ from the original in pagination and typographic detail.

Please cite the original version. 


Abstract (Chapter 15)
The Anarchical Society outlines various possible world orders, such as 'New Mediaevalism'
and world state, as alternatives to the anarchic order of the modern states-system. Chapter 15
evaluates critically the factual and normative premises of Bull's arguments concerning
possible, likely, and desirable future world orders (factual and normative are intertwined but
not inseparable). A key point is that Bull somewhat underestimated the sway of globalizing
of Chapter 15, however, is that because of his omission of political economy, Bull would
have been puzzled about the causes of the re-emergence of great power conflicts. For the
same reason, he also misjudged the importance of building better common institutions.
Bull, causation, globalization, philosophical realism, political economy, war, world state

This is an Accepted Manuscript of a book chapter published by Oxford University Press. The original publication: Patomäki, H., 'The Anarchical Society as Futurology', in H. Suganami, M. Carr, and A. Humphreys, (eds.), The Anarchical Society at 40 : Contemporary Challenges and Prospects, Oxford, Oxford University Press, 2017, pp. 253-269. Reproduced by permission of Oxford University Press. https://global.oup.com/academic/product/the$\underline{\text { anarchical-society-at-40-9780198805144?cc=gb\&lang=en\& }}$ 


\title{
15. The Anarchical Society as Futurology
}

\author{
Heikki Patomäki
}

\section{INTRODUCTION}

The final part of Hedley Bull's The Anarchical Society is dedicated to the exploration of possible future world orders. First, Bull maps the space of possibilities in conceptual terms and then investigates trends towards various possible world-historical ends. He continues by normatively assessing alternatives to the states system and especially to what he calls the international society. Finally, Bull considers a range of transformative ideologies and their plausibility.

The mapping of future possibilities follows logically from Bull's theory of world politics and its conceptual distinctions. Isolated states can exist without forming a system. Bull's reading of Rousseau comes close to this picture of isolated states. States may also interact and be part of a system without forming a society. In this case states and their representatives lack intersubjectively shared rules, norms, understandings, and institutions. The third possible alternative to the current international society is a world state. Bull's perhaps most original insights concern the case of overlapping authority and multiple loyalty. He calls this future possibility 'a new mediaevalism'. Bull also argues that there are many possible variations within the order of international society. The world could become disarmed, ideologically homogeneous, and/or based on 'Grotian' solidarity. Alternatively, a large number of nuclear powers could emerge, generating a universal deterrent system.

In 2017, we may ask, with the benefit of hindsight, whether Bull's interpretations and expectations succeeded in foreseeing the next few decades of world history and, moreover, whether he remains an opportune guide from now on. While Bull represented himself as a 
methodological 'classicist', he did not avoid causal language (1966a). From a scientific realist viewpoint (Patomäki and Wight 2000; Patomäki 2002), we should also enquire whether Bull had an account of the causal powers, mechanisms, and processes capable of generating the trends he either observed or anticipated. Can Bull be read as a philosophical realist or did he, after all, consider causation in empiricist terms? Can we explicate and then assess his implicit premises? What were his typical argumentative schemes?

An interesting thing about The Anarchical Society is the way it situates normative discussions in the context of real world historical developments. The problem with conventional Western normative theory is the tendency to either disconnect values from the real, geo-historical world or see them in empiricist terms as something that is actually shared (Patomäki 1992a; cf. Patomäki 2002, 143-63). Given this, normative theory vacillates between irrealist utopianism (when values are sometimes seen as transcendent, i.e. otherworldly) and mere justification of the present (typically when values are conceived in terms of actual tradition or consensus or something similar).

Bull's approach is different. His normative judgements are based on a mixture of considerations, in which actual, possible, and likely world-historical developments play a crucial role. This does not mean, however, that his judgements are always correct or even plausible. I will evaluate critically the factual and normative premises of his arguments (the two are intertwined but not inseparable). My main argument is that because of his omission of political economy, Bull would have been puzzled about the causes of the re-emergence of great power conflicts. For the same reason, he also underestimated the importance of building better common institutions.

\section{WORLD-HISTORICAL TRENDS AND TENDENCIES}


How did Bull's interpretations and expectations succeed in foreseeing the next few decades of world history? At first look, Bull seems to have done much better than most in terms of anticipating the future. At the general level of systemic transformations, Bull was markedly right about the continued existence and prevalence of the international society. The most obvious omission was that Bull did not anticipate the end of the Cold War, yet we know that it came as a surprise to most IR scholars, Deutsch (1954) being a rare exception (see Allan and Goldmann 1992, including Patomäki 1992b, for an ex post evaluation of IR theories in this light). It is also noteworthy that in the post-Cold War era, the world has both avoided disasters such as a large-scale nuclear war and eschewed systemic changes.

International society has not degenerated into a Hobbesian system of interactions. Ideological tensions were reduced, at least at first, by the unexpected end of the Cold War, although new tensions have risen since then. In Bullian terms, the world has experienced a return to a pre-First World War situation of largely shared liberal or liberal-authoritarian values, although various fundamentalisms have risen to challenge the secular, science-based, and materialistic values of the (il)liberal and globalizing capitalism (Ruthven 2007). The rules and institutions of international society have not disappeared but evolved; yet a world state proper is not in sight. Some of the trends towards a new medievalism have continued, but while they may constitute anomalies and irregularities from the point of view of the states system, these trends have not outdone the institutions of international society in the post-Cold War era, rushed accounts such as Ruggie (1993) and Friedrichs (2001) notwithstanding.

It may be countered, however, that the European integration process has brought about a qualitative change in Europe. In the 2010s, the European Union is a complex hybrid of an international organization and a state (Caporaso 1996 is a well-known attempt to theorize this ambiguity in terms of different forms of state). Despite the British exit from the Union (due by 2019), which reinforces the institution of state sovereignty in Europe, a real doubt persists 
both in theory and in practice as to whether sovereignty lies with the national governments or with the organs of the EU. This ambiguity was demonstrated in a particularly authoritarian way by the Greek debacle in the summer of 2015. Bull maintained that from a global perspective, the EU's hybrid nature would not make any major difference:

But such a state of affairs, if it existed in Europe, would not mean that the global states system had been eclipsed, only that in this particular area (as, in the early centuries of the states system, in Germany), there was a hybrid entity which did not conform to the prevailing norms. $(1977,266)$

One could further argue in Bull's favour that since the breakdown of the Soviet Union and Yugoslavia, the disintegration of states has halted and the number of states has stabilized. In the 2010s, non-state groups engage in violence and state-violence is privatized to a significant degree, but from a Bullian point of view, there is nothing radically new either in 'freedom fighting' or 'terrorism', or about mercenaries and trading companies that command armies. Trends towards new medievalism have spawned counter-trends. States have continued to try to limit and regulate non-state violence. This dialectic has also generated new-even if only limited forms - of global governance. (Avant 2016; for a critical discussion, Patomäki 2016).

What goes somewhat against the expectations of Bull is that since 1977 transnational organizations have further proliferated. Bull seems to have underestimated both the sway of globalizing forces (Scholte 2005) and ignored the possibility of the emergence of at least some elements of world statehood (cf. Albert et.al. 2012; Albert 2016). Transnational corporations, banks, and financial investors are arguably more powerful than ever (as pointed out already by Gill and Law 1989). New free trade and other international legal agreements have consolidated the privileged position of private mega-corporations. Globalization may not be as new or discontinuous as sometimes depicted, but qualitatively novel features and properties have emerged, from investment protection clauses and just-in-time systems of 
global production to computerized derivatives markets and aggressive tax planning. These trends, strengthened further by processes of technological unification, are perhaps the clearest sign of the world system moving towards Bull's new medievalism.

Bull did not fully acknowledge that the line between neo-medievalism and a world state is necessarily blurred. Concepts are not containers with clear-cut insides and outsides. While no proper world state may be in sight, it can be maintained that at least some elements of world statehood exist already, involving the possibility of making binding collective decisions and creating new law. When the state is understood as a trans-historical universal notion, there is no reason to reduce it to one particular instance such as territorial nation-state. Different overlapping forms of modern state authority can coexist within the same space. True, we may concur that the processes of global constitutionalization may be legitimized only partially and are mediated through established territorial states. ${ }^{1}$ They are also best understood in terms of functionally specific global constitutions, in plural, rather than in terms of a single overarching formal constitution, even when these processes have deep historical roots in pre-modern moral and legal developments. The relevant legal rules and principles concern especially human rights and private property rights, but involve other tenets as well. (Albert et.al. 2012; Albert 2016; Brunkhorst 2012).

\footnotetext{
${ }^{1}$ Jessop argues that a world state is unlikely to become the dominant scale within any system of multi-spatial metagovernance, especially in a networked, asymmetrical, and still hierarchical world of states (2012). At the same time, Jessop also maintains that the problematic tendencies, antagonisms, and contradictions of the capitalist world markets — which are now 'ecologically dominant' — well justify various political efforts to build a world state. The point of these transformative efforts is to 'limit the ecological dominance of capital accumulation (including its increasingly damaging environmental footprint) and provide other ways to steer the overall development of world society' $(2012,202)$.
} 
Their inherent limitations notwithstanding, processes of global constitutionalization are real and qualitatively different from Bull's categories of different systems. It is also important that the emergence of elements of world statehood has given rise to new forms of agency and politics. At least rudiments of global public sphere and an outline of global civil society have evolved from the 1980s through to 2010s, as a critical response to global problems and, ever so often, in opposition to the evolving neoliberal world order. Sometimes civil society organizations advocate liberal human rights and democracy across the world, thus contributing to the on-going processes of global constitutionalization. Recurrently civil society actors react to global problems and contest the dominant systems of global rule, suggesting alternative steering powers, rules and principles, and sources of legitimation, in their stead (O'Brian et al. 2000; Scholte 2011; see also Patomäki 2011 on the idea of a world political party).

Hence, while Bull may have been right about the continuing existence and prevalence of international society, he seems to have underestimated the sway of deep-seated globalizing forces. The increasing power and reach of transnational organizations and the emergence of elements of world statehood appear to be to a degree at odds with Bull's expectations concerning possible transformations of the states system.

What about possible changes within international society? After the end of the Cold War, the world became ideologically more homogeneous and, subsequently, there were attempts to build systems of collective security or, beyond that, even elements of world statehood in the functionally differentiated sphere of security (United Nations 1992). In the absence of consensus at the UN Security Council, however, the US and its NATO allies have oftentimes resorted to unilateral wars of intervention. As Bull stressed in The Anarchical Society, the problem with the accounts of just war is that just causes may and often do clash, whether in the public sphere or on the battleground $(1977,30,132-3,157-8)$. This has clearly been the 
case in the Middle East and Central Asia. Bull also stressed that attempts at collective security may weaken or undermine 'classical devices for the maintenance of order' (1977, 231). If one great power can resort to war unilaterally, why not the others? The conflict between Putin's Russia and the West can be seen from this perspective as a possible and likely consequence of the unilaterally executed version of collective security by the post-Cold War US and its allies; this unilateralism has amounted in effect to the revival of the just war doctrine. In the Syrian civil war (2011-), too, conflicts over the just cause are interwoven in complex ways, with potential not only for some cooperation but also for further escalation of antagonisms and conflicts.

The world has become neither disarmed nor characterized by a universal deterrent system. The 'peace dividend' of the end of the Cold War turned out short-lived. By 1997-99 it was over and not only in Europe but globally. In the 2010s, world military expenditure exceeds Cold War levels in absolute terms, with East-Asia playing an increasingly prominent role (military spending in Asia and Oceania rose by 64 per cent between 2006 and 2015; Perlo-Freeman et al. 2016). Nuclear proliferation has nonetheless been slow, slower than what many anticipated in the 1960s and 1970s. Underneath sensational media events and the daily drama of world politics, and in spite of some gradual changes and persisting potential for a global catastrophe, the overall situation in 2017 appears to be mostly that of business as usual within the international society setup. This is in line what Bull expected forty years ago.

\section{BULL'S ACCOUNT OF CAUSATION, SOCIAL}

\section{SCIENCES AND FUTURES STUDIES}

What explains the prevailing or future order or disorder of world politics? Bull's own analyses and anticipations rest on a limited set of argumentative schemes. On occasion he 
made an explicit connection between explanation and causation. Bull $(1977,74-6)$ clarifies that his claims about connections between rules, institutions, and order are causal rather than functionalist. He even tries to formulate an account of efficient causation in terms of necessary and sufficient conditions:

A central theme in this study is that the rules and institutions to which reference has been made carry out positive functions or roles in relation to international order. In this study what is meant by statements of this kind is simply that these rules and institutions are part of the efficient causation of international order, that they are among the necessary and sufficient conditions of its occurrence. $(1977,74-5)$

Beyond this there is little about causation in The Anarchical Society. In the 'case for a classical approach', Bull explicates his methodological stance. He gives several reasons for the claim that 'the practitioners of the scientific approach are unlikely to make progress of the sort to which they aspire' (1966a, 369-70). ${ }^{2}$ Thus instead of relying on quantitative world order modelling or any other approach trying to test causal claims in a systematic empirical fashion, Bull tries to understand large-scale world-historical developments and their implications in qualitative-historical terms.

Primarily, Bull studies world politics through discussing the relevant literatures. He (re)constructs and assesses other scholars' arguments concerning large-scale developments.

\footnotetext{
${ }^{2}$ It is worth comparing Bull's proclamation with Vasquez's (1996) devastatingly critical assessment of the main claims and hypotheses of political realism (and to a degree liberalism as an IR theory too). Vasquez reaches the conclusion that 93 per cent of political realist hypotheses have been falsified and only about 2 per cent passed the test of high association, including those derived from the most central realist claims (power, alliances). Those not-yet-falsified will be soon falsified.
} 
He acknowledges the limitations of making such indirect observations and arguments, stressing that our 'general propositions cannot be accorded anything more than the tentative and inconclusive status appropriate to their doubtful origin' (1966a, 361). The key notion here is judgement. Bull relies explicitly on the exercise of judgement, noting that the most important questions are as often moral as empirical-historical. He also makes some logical, political theoretical arguments. For instance, he points out that any argument for a world state that starts with a Hobbesian description of the states system is incoherent:

But if states are indeed in a Hobbesian state of nature, the contract by means of which they are to emerge from it cannot take place. For if covenants without the sword are but words, this will be true of covenants directed towards the establishment of universal government, just as it will hold true of agreements on other subjects. $(1977,262)$

Bull adds rather categorically, however, that there is no empirical evidence that states would be willing to subject themselves to the rule of a world state. Bull did not have the opportunity to hear Gorbachev in the late 1980 s advocating solutions to global problems by means of establishing a world government; neither did he see the literature on global democracy that resurged after the end of the Cold War (the debate had of course begun during the world wars; see Held and Patomäki 2006). Bull might counter that even if we may now see some weak signs of a world state, there is no credible basis for such a global transformation. Wishful thinking is not a good basis for rational judgements or actions. Rather, what appears particularly important today, in 2017, is that the world is sliding back to nationalist statism and conflicts.

Whether Bull would dismiss the argument concerning overlapping forms of modern state authority within the same space, implying that at least some elements of world statehood have evolved, is more uncertain. Bull's scepticism about a world state is based to an 
important degree on normative considerations. At times Bull resorts to conservative remarks along the lines of 'haven't we already tried all this consciousness-raising stuff' $(1977,303-$ 4). His main argument is, however, that a world state in itself would not solve the problem of collective violence — or any other global problem. In an argumentative scheme that is characteristic to The Anarchical Society, Bull points out that if we can imagine utopian possibilities in relation to a world state, we can also imagine them in relation to alternatives such as international society:

Of course we can imagine a world government which would not lend itself to civil or internal violence, at least on a large scale, because in it there were institutionalised procedures for the peaceful resolution of conflicts that allowed for change and were generally accepted as legitimate. Under such a world government, as within some modern Western states that have a high degree of political stability and a relative absence of violent internal conflict, large-scale violence might be avoided for long periods. But if we are free to attribute to our imagined alternative form of universal political organisation these utopian features, we are also free to think of the states system in these utopian terms, as a system in which the conditions of a 'pluralistic security-community' are generalised. $(1977,285)$

Deutsch and his associates introduced the notion of security community (1957; Lijphart 1981; Patomäki 2002, 193-209). Deutsch argued that the existence of the state is neither a necessary nor a sufficient condition for peace; nor is the non-existence of the state a necessary or a sufficient condition for the prevalence of the acute threat of political violence. These connections are contingent. The imposition of a common government, with its capacity for violent enforcement of norms, may well decrease rather than increase the chances of peace. The real difficulty lies in building a community within which conflicts can be resolved 
by institutionalized peaceful means and procedures. ${ }^{3}$ In this Bull agrees with Deutsch. He also uses the same argumentative scheme in the contexts of economic and social justice and the environment. In each case, for Bull a world state is neither a necessary nor a sufficient condition for tackling a global problem.

Bull's standard scheme of argumentation is thus abstract and mostly negative. In social sciences it is rather easy to say that $\mathrm{X}$ is neither a necessary nor a sufficient condition for outcome $\mathrm{O}$, because strictly speaking nothing ever is (conditions function only as part of a geo-historical context). The level of abstraction is too high. Apart from the Deutschian mechanism of resolving conflicts peacefully, Bull does not specify any causal powers, mechanisms, or processes that we should take into account in analysing specific global problems. For instance, he mentions 'deeper causes' of economic and social injustice but does not explain them $(1977,291)$.

Bull was not a positivist, except probably in the sense of legal positivism (following Hart 2012). On the other hand, whether he can be read as a philosophical or scientific realist seems open to doubt. Bull did not have the conceptual resources to resolve the aporia of general causal statements vs. historical changes and idiosyncrasies. He criticizes positivism (behaviouralism, scientism) in terms of open systems ontology and double hermeneutics of social sciences, but at the same time he is rather vague about his own ontological assumptions

\footnotetext{
${ }^{3}$ Neither Deutsch nor Bull explored connections between the possibility of peaceful changes and democracy. I have argued elsewhere that democratization of social contexts (including trans-and supranational contexts) and the development of security community can be mutually supportive (Patomäki 2003). This is not always the case, however. Since the development of a security community is a long and complicated process of institutionalization of mutual acceptance, trust and procedures and practices of peaceful change, and since it is always vulnerable to the escalation of conflicts, an inconsiderate attempt at global democratization may turn out to be counterproductive.
} 
and existential hypotheses. ${ }^{4}$ Many of his methodological statements are formulated in an imprecise and at times ambiguous manner (see also Bull 2000d). Bull did not develop a systematic methodological stance. Kaplan's criticism of 'traditionalism' as 'undisciplined speculation devoid of serious substantive or methodological concerns' is not entirely unfounded $(1966,20)$.

\section{ON THE LIKELY CONSEQUENCES OF THE STATES}

\section{SYSTEM: A POLITICAL ECONOMY PERSPECTIVE}

Despite the limitations of his approach, it is fair to say that often Bull's arguments remain sound, and many —although not all—of his judgements about possible and likely futures have been at least somewhat on the mark. This is in contrast to the bulk of political observers who fail miserably with their anticipations and are often bad at updating their beliefs on the basis of evidence. Tetlock (2005) uses Berlin's (1953) metaphor of foxes and hedgehogs 5 and argues, on the basis of large-scale empirical studies on expert judgements, that foxes overpredict fewer departures, good or bad, from the status quo. Yet foxes do not mindlessly predict continuity from the past. In market terminology, they 'are hedging their bets' by

\footnotetext{
${ }^{4}$ It seems likely that he had not heard about the arguments of Harré and Secord (1972), Keat and Urry (1975), and Bhaskar (1975), although they were developed and widely discussed in philosophy and social theory at the time when Bull was writing The Anarchical Society in the 1960s and 1970s.

${ }^{5}$ Foxes are those who 'know many little things', drawing from an eclectic array of traditions. Foxes accept ambiguity and contradiction as inevitable features of life. Bull was a fox in this sense. Hedgehogs are those who 'know one big thing', toil devotedly within one tradition, and reach for formulaic solutions to ill-defined problems (Tetlock 2005, 2).
} 
rarely ruling out anything as impossible. Their strength lies in open-mindedness and cautiousness.

The assumption of business-as-usual works only until things change. A self-critical, dialectical style of reasoning can spare experts from many mistakes. Foxes are usually better at learning from mistakes. The problem is that too much open-mindedness can amount to mere old-fashioned confusion (all possibilities are covered and thus whatever happens seems compatible with one's anticipations). I would characterize Bull as a fox rather than a hedgehog, indicating that he was capable of balancing his judgements. Foxes are especially sensitive to how forces drawing to different directions often cancel out and result in relative stability.

Bull was less good at explicating how absences and contradictions drive political changes. ${ }^{6}$ It is difficult to analyse the historical dynamics of a system without a sufficiently deep account of its underlying structures and mechanisms, or the logics and patterns of its evolvement. The mere absence of necessary or sufficient conditions for a particular outcome does not explain much, nor does it give a genuine basis for anticipating possible and likely futures. Knowledge about history and some casual observations about prevailing trends and tendencies may give more substance to one's judgements, but they are not sufficient for building systematic scenarios about possible and more or less likely and desirable futures. The fact that there is no organized account of underlying causal powers and mechanisms, of relevant contradictions (problems, lacks, etc.), and of related geo-historical processes, means

\footnotetext{
${ }^{6}$ Bhaskar (1993) develops multifarious dialectical categories and schemes for understanding change at all levels of reality, but focusing especially on contemporary world history. I apply some of these categories and schemes to the analysis of dialectics of global governance in the twenty-first century, initially understood in terms of a simple Polanyian double movement, but then developed into new and more open-ended and normative directions (Patomäki 2014).
} 
that judgements about possible futures must be made in part in darkness. What is more, Bull's analysis excludes political economy considerations almost entirely.

A particularly pertinent question for Bull in 2017 is this: why was the post-Cold War moment of cooperation, shared values, and solidarity so short-lived? Why is the world sliding, again, back to nationalist statism, militarized conflicts, and arms race, notwithstanding the sway of globalizing forces and emergence of elements of world statehood? Perhaps the answer can be found, in part, in the dynamics of global political economy, which forms a complex process in which actors and issues are actively interwoven. ${ }^{7}$ Politico-economic interconnectedness applies to developments in every region of the world, as the dynamic processes of the world economy shape conditions everywhere. The whole is more than the sum of its parts; but the whole does not work without its parts. Actors do participate in bringing about and steering global political economy processes in various ways, but often in short-sighted or contradictory ways (Patomäki 2008; Patomäki 2013).

How does the world economy work from a Bullian point of view? It is well-known that there is hardly anything about the political economy of peace and security in The Anarchical Society. In this rare passage on political economy Bull seems to be committed to the logic of economic liberalism:

\footnotetext{
${ }^{7}$ To qualify my earlier remarks on political realism (n. 2), it must be acknowledged that classical political realism can illuminate some of the key causes for this regression in world politics in the 2000s and 2010s. Morgenthau's systematic critique of the temptation of universalism (1961, 11, ch. 7, ch. 20, 560-70); and Carr's (1946, ch. 4.) equally forceful critique of economic liberalism's utopia of harmony of interests; can shed light on the deep structures of meaning that have, once again, turned out counterproductive. In a telling phrase, Carr talked about 'the paradise of laissezfaire'.
} 
The states system, it may be argued, obstructs realisation of the goals of economic and social justice in two main ways. Because it imposes barriers to the free movement of men, money and goods about the earth's surface-and also to their movement according to a putative global plan of economic development - it inhibits world economic growth. $(1977,289)$

Bull does not go so far as to say that free trade is good for peace. Rather he is either ignorant or agnostic about the debates that concern the institutions and mechanisms of capitalist market economy and their internal and external relations to processes such as expansion, securitization, escalation of conflicts and preparedness for war.

Consider the case of the major mid-2010s conflict centring on Ukraine. The immediate background for this conflict has to do with NATO and EU expansion eastwards. Russian leadership has been progressively more determined to draw a line, especially at NATO, but also at EU expansion. ${ }^{8}$ This is connected to a particular interpretation of political changes in the former Soviet Union and the Balkans during the early 2000s. The Russian state-leaders have been disposed to interpret the so-called colour revolutions as a deliberate strategic means of the expansion of the West and its particular values eastwards. In the words of Foreign Minister Sergei Lavrov: "The US and Europe use the "Color Revolution" to serve their own interests, impose their own values, and end in creating new global tensions' (Cordesman 2014).

${ }^{8}$ There is a long-standing dispute about whether NATO's expansion into Eastern Europe violated commitments made during the negotiations over German reunification. Russian leaders have accused the West of breaking promises made after the fall of the Iron Curtain. Der Spiegel argued in 2009 that 'newly discovered documents from Western archives support the Russian position'. For a discussion of these documents, see Klußmann et al. (2009). 
The precise extent to which uprisings in the early 2000s in Serbia, Georgia, Ukraine, and elsewhere were in fact supported, encouraged, funded or even systematically planned by the US and the EU (or its member states) remains disputed. What we know for sure is that the securitization of these uprisings on the Russian side have triggered at times rather exceptional countermeasures, ${ }^{9}$ which in turn have led to unintended counterproductive effects, not the least in Georgia and Ukraine (Delcour and Wolczuk 2015). In this process of step-by-step escalation of conflict, the universalizing inner grammar of Western neoliberalismmanifesting itself through various free market arrangements, neighbourhood policies, and programmes of democracy and human rights promotion - has come to be contested and geopoliticized, even though Russia itself combines elements of state capitalism and neoliberalism in its economic policies and institutional arrangements.

It is evident that many corporate and state actors benefit (or would benefit) from an easy or privileged access to raw materials, cheap labour, industrial capacity or markets in the

\footnotetext{
${ }^{9}$ Already before the 2007-8 elections, there was much public talk in Russia about the danger of a 'colour revolution'. Academic analysts have been torn between two different interpretations. Some argue that securitization has served Putin's regime in domestic politics; whereas others think that the anxiety of leading Russian politicians is genuine. Duncan (2013) concludes his analysis of 2007-8 that 'fear of a coloured revolution was, it seems, not fabricated with the intention of being used instrumentally to preserve the regime'. The fear seems genuine, but do the dominant beliefs in Russia conflate concerns about ruling elite's position and the interests of society at large? While a nuanced answer to this question lies beyond the scope of my paper, it is worth noting that White and McAllister (2014) consider the possibility that Russia only scarcely avoided a 'Facebook Revolution' in 2011. Given Putin's popularity in Russia, a 'revolution' in 2011 was unlikely. Yet a new phase in securitization was reached in 2013-14. Since Ukraine's EuroMaidan, Russia has framed mass anti-regime protests at home and abroad as a military threat. (Bouchet 2016)
} 
Eastern Europe, former Soviet Union, and the Balkans. Constructivists are right, however, in stressing that interests are not separate from beliefs but constituted by them (Wendt 1999, 119-38). Interest-constituting beliefs are frequently disputed. For instance, EU's democracypromotion is built on the neoliberal model of market society. It allows for some pluralism and exploration of extra-liberal ideas, and this is what civil society actors often do. And yet, there are reasons why 'all such ideas are swiftly returned to the magnetic field of (embedded neo)liberal core assumptions' (Kurki 2012, 172). Particular beliefs may come to be selected and pushed because they accord with the already-constituted powerful interests. Yet political economy explanations are not reductionist. They take the concept-dependency of social beings seriously. Interests are only moments in social processes.

Once a particular institutional arrangement is in place, it affects the structuring of mechanisms that subsequently tend to bring about particular characteristic causal consequences, shaping the processes of global political economy in which actors are active and issues are interwoven. Thus the conflict in Ukraine was precipitated by a global crisis. The worldwide process of financialization has deepened cycles of boom and bust and made them synchronized across the world. The financial crisis of $2008-9$ was the most serious crisis of the world economy since the Great Depression and the Second World War (Patomäki 2010). As a result of the crisis, Ukrainian GDP collapsed by almost 15 per cent in 2009, ending a decade of high economic growth and decreasing poverty. Following a shortlived, half-way recovery in 2010-11, recession and then depression continued. Soon Ukraine faced a situation of mounting debt and rapid loss of currency reserves. The current account in Ukraine reached a record low of -6 USD billion in the third quarter of 2013 . At the same time, foreign currency reserves were rapidly approaching an all-time record low of 5 USD billion. 
European and North American lenders started to assume, or directly demand, austerity. The problem is that austerity and financial problems easily become self-perpetuating and translate into high levels of unemployment, uncertainties, and economic troubles of everyday life. A further problem is that unemployment and economic uncertainties can aggravate social antagonisms. Unemployment is an issue of existential security and thus creates room for securitization of political issues; this applies to socio-economic uncertainty more generally. ${ }^{10}$ In the Ukrainian context, economic hardship is easy to associate with corruption and concentration of wealth.

The Euromaidan protests started in November 2013, when the Ukrainian president Viktor Yanukovych began shying away from an association agreement that had been negotiated with the EU. Instead, he chose closer ties with Russia. The EU had offered a relatively small loan, with conditions similar to the austerity conditions imposed by the

${ }^{10}$ The unemployment rate rose to about $10 \%$ by early 2014 . Unemployment has never been the most important source of poverty in independent Ukraine. On the other hand, in 2015-16 the unemployment benefit is only about 50 USD per month. While the insecurities related to the threat of unemployment are never just economic but also moral and social, this aggravates the threat of unemployment. In terms of GDP growth, there was a half-way recovery of the Ukrainian economy in 2010-11, but from 2012 to 2015 Ukraine's GDP contracted again first modestly and then sharply. These developments preceded the political crisis associated with the demonstrations and riots of late 2013 and early 2014. By the end of 2015 the GDP of Ukraine had contracted back to the 2005 level. (World Bank data available at http://data.worldbank.org/indicator/NY.GDP.MKTP.CD). 
Troika upon the euro crisis countries. ${ }^{11}$ Criticism of those conditions fed into the East-West and other divides in Ukrainian political economy and society.

In February 2014, Ukraine appeared to be on the brink of civil war, as violent clashes between protesters and special police forces led to many deaths and injuries. Yanukovych fled to Russia. He was removed from office by the parliament of Ukraine in a manner that violated the then-current constitution. In March 2014, in response to the illegal ousting of Yanukovych, the Supreme Council of Crimea organized a referendum in Crimea. The majority of Crimean people seemed to favour joining Russia. Hastily Russia made Crimea a part of the Russian federation - against international law according to a number of UN member states - arguing that the unilateral Kosovo declaration of independence in 2008 had set a precedent. At this time, pro-Russian movements, involving Russian citizens, were protesting against Kiev in Eastern and Southern parts of Ukraine. In the East the situation soon escalated into an armed conflict between the separatist militia supported by Russia and the new Ukrainian government. The war in Donbass started in April 2014 and continues as a low-intensity conflict in 2017.

The lessons from the Ukrainian conflict can be generalized from a global Keynesian perspective. ${ }^{12}$ Processes of politico-economic expansion and uneven growth in the context of

${ }^{11}$ Austerity tends to depress the economy. These packages also impose retrenchment on public services and distribution policies, wage and pension cuts; and impel changing labour laws under the euphemism of 'flexibility' or 'flexicurity' - typically, also implying wage cuts, thereby lessening citizens' purchasing power and further reducing overall effective demand. (On the effects of the Euro crisis and austerity, see Patomäki 2013, 57-81).

${ }^{12}$ Already Keynes' own experiences in the 1910s convinced him that economic theories cannot adequately be applied solely at national level; a holistic world-perspective is needed. This implies that issues of the economy and international relations are tightly interconnected. (Keynes 1920; 
a contradictory and unstable world economy can (co-)generate, (re-)trigger, and escalate conflicts that are always embedded in specific geo-historical setting, with complex backgrounds. After a point, escalation may start to follow its own logic. A number of mechanisms and absences contribute to this outcome. There is no automatic mechanism balancing trade, or supply and demand, or synchronizing diverse economic processes. Increasing inequalities is an important reason why there may be not only a lack of legitimacy but also of inadequate overall demand in the economy. Insufficient demand at home is a problem that states can try to export to other states, for instance by means of pushing for maximal or privileged access to geo-economic spaces, or by resorting to internal or currency devaluation (which lowers the price of exports, making them more competitive in markets, but other states can respond in kind).

When states commit a fallacy of composition in their external policies (i.e. try to improve their situation or position by non-generalizable means), they not only reduce aggregate demand in the world economy but also risk potential conflicts with other states, which may be simultaneously engaging in similar projects. Typically, inadequacies in the overall efficient demand translate into the under-utilization of production capacity and thus unemployment. Since the 1980 s, various forms of precarious work have also become more common. High levels of unemployment and uncertainty tend to generate existential insecurity among the citizenry, forming fertile ground for the rise of antagonistic self-other relations and exclusive nationalism. Capitalist world markets and the states system involve plenty of conflict potential.

Markwell 2006) Global Keynesianism is an approach that frames questions of public economic policy and politics on the world economic scale (Köhler 1999). 
Many politico-economic processes are self-reinforcing, including processes of (de)industrialization and accumulation of wealth and privileges. ${ }^{13}$ States' attempts to intervene in processes that facilitate or prevent (de)industrialization may be blocked by other states, often in the name of free trade. In the 2010s, the principles of free trade are neoconstitutionally secured (Gill 1998). Attempts to block forms of state interventions in the economy can be, and often are, in accordance with the interests of those actors who currently benefit from cumulative causation in the world economy (this is the classical, but contested Listian argument).

Also inequalities of income and wealth among individuals and social classes tend to accumulate. A key argument of Piketty's (2014) is that there is a tendency for $r>g$, where $r$ is the average annual rate of return on capital and $\mathrm{g}$ is annual economic growth. Past wealth becomes increasingly important and inherited wealth grows faster than output and income. If this is combined with the inequality of returns on capital as a function of initial wealth, the result is an increasing concentration of capital. Moreover, this process is likely to lead to the accumulation of political privileges and hence de-democratization. Thereby the concentration of capital also shapes the production and distribution of knowledge in society. The selection mechanisms for dominant beliefs, narratives and discourses become skewed towards reinforcing the appropriate beliefs and societal interests as defined by the wealthy and powerful or those representing them. At worst, anything perceived as threatening to basic

${ }^{13}$ On the concept of cumulative and self-reinforcing causation in economics, see Kaldor (1972, 123755); and on positive feedback loops and self-reinforcing processes in politics, Pierson (2004). For a similar recent analysis of the role of technology gap in trade and uneven growth, see Cimoli and Porcile (2011). In Patomäki (2008, 124-55) I analyse the role of positive feedback loops in the political economy of global security developments. 
beliefs and stories may come to be securitized; and anyone disagreeing with the established direction may be constructed as a potential or actual enemy. ${ }^{14}$

These processes matter from the point of view of international and global security. They strengthen the relative power of actors predisposed to disregarding those rational economic policies needed to ensure full employment and steady economic developments. For instance, growing inequalities tend to reduce overall demand and encourage financialization. Thereby the likelihood of major economic crises and shocks increases. Moreover, de-democratization, securitization, enemy-construction, and inverted totalitarianism (Wolin 2010) are likely to generate and aggravate antagonistic relations with different others. The real problem is that this trend towards increasing inequalities is difficult to reverse. Historically, only major shocks, (especially world wars), interwoven with processes of democratization, have been sufficient for invoking progressive taxation and other causally efficacious measures to reduce inequalities (Piketty 2014, 18-20, 41, 141, 287, 471, 498-500; Piketty's argument finds support in the history of modern taxation, Scheve and Stasavage 2016).

${ }^{14}$ Also NATO's eastward expansion has been premised on particular but shifting forms and objects of securitization. Meanwhile in Russia and Ukraine, the initial private wealth distribution that resulted from shock therapy and privatization of the state assets in the early 1990s have been causing turmoil and counter-reactions. In most of the OECD world the Pikettyan 'law' seems to hold and inequalities have been rising gradually. In Russia in the 2000s, Putin's regime reversed the worst excesses of the 1990s and stabilized the socio-economic situation, in the context of solid economic growth benefiting also ordinary citizens. Now the Gini index in Russia is roughly on par with those of the US, China, and Mexico. See n. 9 for a discussion on how this may have affected processes of securitization in Russia. In Ukraine, the Gini index has been lower, but the wealth concentration more extreme. 
It is time to return to The Anarchical Society. Bull participated in the problematical functional differentiating between domains of security and political economy by focusing on diplomacy and statecraft and by ignoring political economy. The progressively ever more institutionalized division of labour between security studies and political economy makes it difficult, if not impossible, to give an adequate account of the causal powers, mechanisms, or processes that underlie world-historical trends and tendencies related to peace and war. The separation of politics from economics affects one's judgement about the potential for new crises, antagonisms, and conflicts. It also affects our normative judgements about future possibilities. The system of states in the capitalist world economy seems increasingly dysfunctional. It is widely acknowledged that political economy contradictions are best overcome by means of collective actions and institution-building. The process of institutionbuilding has potential for transforming the very nature of world politics.

\section{Conclusions}

In the conclusions of The Anarchical Society, Bull states that the overall argument of his book 'is an implicit defence of the states system', and this concerns especially the elements of international society, which should be preserved and strengthened (1977, 218). Going beyond mere 'Grotian' thinking and international society, Bull also expressed his commitment to critical cosmopolitanism:

World order, or order within the great society of all mankind, is not only wider than international order or order among states, but also more fundamental and primordial than it, and morally prior to it. The system of states has constantly to be assessed in relation to the goal of world order. $(1977,319)$ 
Normative and empirical claims are interwoven but not entirely inseparable. Despite being (usually) a critical cosmopolitan in moral terms, Bull also maintained that claims about the actual historical decline of the states-system are unconvincing. This is not the end of Bull's story about the future of world politics, however. Bull stressed that 'such a conclusion stands in need of continual re-assessment' $(1977,319)$.

In this chapter I have provided reasons for a reassessment of Bull's main conclusion about our future possibilities. Bull not only underestimated the sway of globalization and the power of transnational organizations but, perhaps even more importantly, his classicist methodological orientation kept him away from explicating systematically those causal powers, mechanisms and processes that generate events, episodes and trends of world politics. Moreover, Bull took for granted the division of labour between security studies and political economy and thus underestimated the explosive potential of the states system within the capitalist world economy.

In the 2000s and 2010s, diplomatic discourse has, once again, gradually declined while a new geopolitical orientation has gained ground. Both nationalism and military expenditures have risen. The problem is that many social processes, also when they originate from contradictory rules, principles, and effects, are self-reinforcing. After a critical turning or tipping point, the dynamics of a self-reinforcing process, characterized by positive feedback to at least some actors, tends to support and institutionalize the original choice or choices. Dynamics triggered by particular events or processes at one point in time may reproduce themselves or accelerate, even in the absence of the recurrence of the original events or processes (Pierson 2004). If positive feedback loops dominate, as they tend to do in global political economy, the world may now be heading towards a global military catastrophe.

Both world history and critical-cosmopolitan normative judgements point towards overcoming the states system. Bull's international institutions have nothing to do with 
economic governance. Political economy contradictions are best resolved by means of collective actions and institution-building. We need adequate mechanisms for world economic policy and new, well-functioning elements of world-statehood.

The Bullian perspective makes it difficult to think about forms of agency and strategies that could lead to such fundamental transformations. What is more, institutions cannot be built without considering their legitimacy. Thus we have to go beyond Bull in engaging with world political theory, by opening up questions about global democracy_-bearing in mind that democracy involves argumentation and debates over the meaning and substance of democratic self-determination itself. 